\title{
INVESTIGATION OF SUSTAINABITY AND FINANCIAL SUSTAINABILITY CONCEPTS IN THE HEALTH SYSTEM ${ }^{1}$
}

Özlem ÖZER ${ }^{2}$

Hasan Hüseyin YILDIRIM ${ }^{3}$
Received Date (Başvuru Tarihi): 24/10/2018

Accepted Date (Kabul Tarihi): 06/12/2018

Published Date (Yayın Tarihi): 04/01/2019

\begin{abstract}
The fundamental element of sustainability in the health system is the financial sustainability that is at the heart of the health policy debate. Factors such as the aging of the world population, the emergence of new technological developments, increasing expectation and demand from the health system, increasing access to health services, and seeking quality health care services have begun to create significant pressures on health systems and threaten the financial sustainability of health systems. Sustainability and financial sustainability are very important concepts in evaluating countries' health systems. However, there are no consensus definitions on these concepts in the literature. The aim of this study is to give information about the concepts of sustainability and financial sustainability, which have become an important topic of discussion in the health systems of the world countries in recent years, and to evaluate these concepts in terms of the health system.
\end{abstract}

Keywords: Health System, Sustainability, Financial Sustainability, Financial Sustainability In Health System

JEL Codes: I15, I13

\section{SAĞLIK SISTEMINDE SÜRDÜRÜLEBILLİRLIKK VE FINANSAL SÜRDÜRÜLEBIILİRLIK KAVRAMLARININ INNCELENMESI}

$\ddot{O} Z$

Sağllk sisteminde sürdürülebilirliğin temeli, sağllk politikası tartışmalarının merkezinde yer alan finansal sürdürülebilirlik konusu olmaktadır. Dünya nüfusunun giderek yaşlanması, yeni teknolojik gelişmelerin ortaya çıkmasl, sağllk sisteminden olan beklentilerin ve talebin artı̧̧ göstermesi, sağllk hizmetlerine olan erişim artması, kaliteli sağllk hizmeti araylşı gibi faktörler sağllk sistemleri üzerinde önemli baskllar yaratmaya başlamış ve sağllk sistemlerinin finansal sürdürülebilirliğini tehdit eder bir hale gelmişstir. Sürdürülebilirlik ve finansal sürdürülebilirlik ülkelerin sağllk sistemlerini değerlendirmede oldukça önemli kavramlar olmasına rağmen literatürde bu kavramlar hakkında henüz üzerinde fikir birliğine varılmış tanımlamalar bulunmamaktadır. Bu çalışmanın amacı da, son ylllarda tüm dünya ülkelerinin sağllk sistemlerinde önemli bir tartışma konusu haline gelen sürdürülebilirlik ve finansal sürdürülebilirlik kavramları hakkında bilgiler vermek ve bu kavramları sağllk sistemi açısından değerlendirmektir.

Anahtar Kelimeler: Sağlık Sistemi, Sürdürülebilirlik, Finansal Sürdürülebilirlik, Sağlık Sisteminde Finansal Sürdürülebilirlik

\footnotetext{
${ }^{1} \mathrm{Bu}$ çalışma, ilk yazarın doktora tezinden üretilmiştir.

${ }^{2}$ Dr. Öğr. Üyesi, Burdur Mehmet Akif Ersoy Üniversitesi, oozer@mehmetakif.edu.tr,

${ }_{3}^{3}$ Prof. Dr. Sağlik Bilimleri Üniversitesi, hhy@tuseb.gov.tr,
} 


\section{INTRODUCTION}

Today, the production and consumption of health goods and services are carried out through modern health systems shaped by socioeconomic, historical, cultural, legal, political and other dynamics of countries (Yıldırım, 2015). A health system refers to entire activities consisting of supply, demand, management, resources, organization, financing, legislation and policies of health services. Any health system has three primary goals: to improve the health of the population, to respond to people's expectations, and to provide financial protection against the costs of ill-health (WHO, 2000). In addition to these three primary goals, health systems have many other goals such as access to health services, participation of the society, sustainability, and innovation. These secondary goals might also affect the level of health, responsiveness to the expectations and aquity in health care (Murray and Frenk, 2000).

In recent years, the most widely discussed topics in health systems have been sustainability and financial strength of the system against increased cost pressures. More recently, in some countries, these issues have been coupled with economic crises. In many European countries, the share of health care expenditure in the gross domestic product (GDP) displays significant increase. The ageing of the population, limited resources, the emergence of new technologies, economic growth, higher expectations, and higher costs of health services inputs are among the factors that challenge health systems. These factors lead to rise in costs, thus posing a threat to financial sustainability too (Figueras et al., 2012).

In Turkey, as is the case in most countries, sustainability and financial sustainability of the health system has recently become important topics of debate. However, information on what these concepts mean in the health system is very limited. Therefore, the aim of this study gives information about the concept of sustainability and financial sustainability in health systems, and to evaluate these concepts in terms of the health system.

\section{SUSTAINABILITY}

The measurement and definition of sustainability is very important because sustainability sheds light whether there is actually a political problem, and if any, how the problem can be solved (Di Matteo, 2010). The concept of sustainability began to further manifest itself in the literature in the early 19th century, and appeared in the field of renewable resources such as agriculture and fishery, along with forestry. With the re-emergence of the issue of resources in the beginning of the 1970s, the debates of sustainability have gradually increased in the fields other than agriculture, forestry and fishery-particularly in the field of 
industry. The increase in environmental issues such as air pollution, noise pollution, etc. has shifted debates of sustainability towards the environmental issues (Kaya, 2013). The main feature of the concept of sustainability, which is used in different fields, is that it is about human future and it involves the protection of resources of the field that it is used in (Tiraş, 2012).

Sustainability, which, in terms of word meaning, is called 'the capacity to endure' (Kaya, 2013) is defined in different ways by different circles. It is derived from the Latin sustinere meaning "to hold", "to support" and 'to maintain'. The concept of sustainability was first coined in the field of forestry (Kuhlman and Farrington, 2010; Campbell et al., 2011). Sustainability, which has become a popular goal for societies, has also become a wide-ranging term that can be applied to any enterprise on a local or a global scale for long time periods (Mathaisel and College, 2014). For environment, sustainability assesses whether or not project outputs can be produced without permanent and unacceptable changes in the natural equilibrium. For human beings, it is long-term physical and cultural well-being (Mathaisel and College, 2014). In public financing, sustainability creates a reliable source of revenues for ongoing public spending (Marchildon, 2004).

Sustainability, which is also described as 'the capacity to endure and withstand changing circumstances' (Birch, 2014), is mostly considered as self-sufficiency, and it refers to the capacity of the system to continue its normal activities into the future (Abuor, 2012). In very general sense, if an organization/system is able to survive over a long period of time, and at the same time, has the ability to fulfill its mission, it can be accepted as sustainable (Klaus, 2010).

Another definition of sustainability is to ensure the capability of a system to endure at a certain level (Gruen et al., 2008). In its most general sense, sustainability refers to providing the resources needed by a certain program, sector, or overall economy within a certain slice of time. Therefore, along with borrowing, economic development or economic growth is also subject to the sustainability criteria. Thus, the concept of sustainability is used for progress or development as well (Göktan, 2008).

\section{SUSTAINABILITY IN HEALTH SYSTEMS}

Sustainability in health systems has recently become a priority policy agenda for countries because of the rise in health expenditures, limited resources and increasing share of health spending in the GDP due to the factors such as technological progress, consumer expectations and demographical changes (Thomson et al., 2009). Sustaining the health system in an efficient and effective manner has become one of the major tasks of governments. The 
interested actors tackle with the deadlock between unlimited needs and limited financial resources (Wang, 2010). The continuous upward trend in the costs of health services and usually faster growth in overall health spending than the economy of nations are considered serious threats to the sustainability of health systems (Prada et al., 2014).

Increasing demand for health services and decreasing financing, human resources and other resources available for the delivery of health services, lead to the emergence of 'sustainability gap', and this gap gradually widens. Health systems, in order to survive in the long term, need to have adequate resources to achieve their goals and to adapt to changing environment (Coiera and Hovenga, 2007).

What sustainability in the health system is, what the goals of sustainability in the health system should be, and how these goals can be achieved are still unclear. Despite its popularity as a modern, but yet a cliché new concept, there is not a clear, agreed-upon definition of sustainability of the health system. The concept of sustainability in health systems is defined in different ways in the literature (Prada et al., 2014). Despite the lack of an agreed-upon definition for sustainability in the health system, some definitions provided in the literature are given below.

Knowles et al. (1997) define sustainability in the health system as "the capacity of the system to continue its normal activities successfully in the future" (Knowles et al., 1997). According to another definition, "sustainability is the capacity of the health system to function effectively over time with minimum external input" (La Fond, 1995; Y1ldırım, 2012a). Sustainability in the health system means ensuring that sufficient resources are available over the long term to provide timely access to quality services and timely access to necessary medicament (Romanow, 2002). These resources consist of human resources that include direct service providers such as nurses, physicians, dentists, hospitals, clinics and health care managers; equipment and materials such $\mathrm{x}$-ray and other diagnostic imaging systems; physical resources involving hospital and clinic facilities such as information technologies that support the health system, and financial resources (Marchildon, 2004).

Conceptually, sustainability in health systems can be understood as a dynamic balance relating to the values on which the system is based (affordability, accessibility, acceptability, and quality). Hence, sustainability involves the system, where these values are sufficiently sustained, and where they provide a framework for meaning and actions (Essink, 2012). Sustainability in health systems means ensuring that appropriate and adequate resources are 
available over the long term in order to assure timely access to quality health services that will meet current and future health care needs of the population (BASYS et al., 2005).

The most common challenges faced in ensuring a sustainable health system are an ageing population, financial sustainability of health systems, prevention and control of chronic diseases, rapid progress in health technologies, cost-effectiveness and innovation (European Commission, 2013). Other major challenges are inadequate human resources, inequality, citizens' decreased trust and confidence in the system and services, low efficiency, and changing social expectations. The increase in the costs of health services is a serious threat to the sustainability of the health system (Prada et al., 2014).

A sustainable health system 1) delivers care to the sick resulting in the lowest possible mortality and morbidity 2) provides that care to the greatest possible portion of the population as much as possible, 3 ) provides that as a percentage of GDP, the total cost of care is in balance with other necessary societal costs for the relevant population, and 4) under that system, care delivery is seen as an attractive and satisfying profession (Miller, 2013).

The major criteria for sustainability in respect of the society, are ensuring accessibility and continuity of health services, accessibility of health services in financial terms as well, and in this context, the existence of social security (Deloitte, 2012).

\section{FINANCIAL SUSTAINABILITY IN HEALTH SYSTEMS}

Over the past 50 years, total health expenditures in the OECD (The Organisation for Economic Co-operation and Development) countries have increased faster than the GDP, at an average of $2 \%$ points above the GDP growth (World Economic Forum, 2012). In most OECD countries, the growth of health spending surpassed the GDP growth over the two decades. This trend has increasingly become an important problem since the 2008 crisis (Tordrup et al., 2013). The big amount of resources allocated to health care and their tendency to further rise over time have brought about versatile debates over the financing of the health system in respect of ensuring the sustainability of the system (Alper, 2011). Modern health systems must remain accessible and effective while seeking long-term sustainability. To do this, they have to be fiscally sustainable (European Commission, 2014).

The debates over sustainability of the health system are mostly about financing (Prada et al., 2014; Romanow, 2002). Some argue that the system is not sustainable due to extremely high costs of the health system, and also because it constitutes a very large a proportion of governments' budgets, or it imposes pressure on taxes. Some others who debate over the 
problems with the system, underline the failure in the organization of the system and inefficiency of outcomes. They maintain that there is more than enough money to meet health care needs, and the system should be reorganized. Others have argued that the only problem with the system is the lack of financial resources in recent years. According to them, restoring and increasing the financial resources will solve the problem (Romanow, 2002).

The concept of sustainability in health system, which is frequently debated in the media, and policy and academic circles, is a controversial concept and is open to different interpretations. However, it is rarely debated what financial sustainability means for a health system or how a health system must achieve financial sustainability or what the policy outcomes of the problem are (Thomson et al., 2009).

There is no universally accepted definition of the concept of financial sustainability. This concept can often be defined as a government's ability to sustain its current expenditures, taxes and other fiscal policies over the long term. The government, thanks to its mentioned ability, will be able to maintain its power to govern, or will not face any problem in fulfilling its responsibilities, or will be able to carry out its pre-committed spending (Kalkınma Bakanlığı, 2014).

The concept of financial sustainability in the health system can be defined as the ability of the health system to generate sufficient resources to fulfill the responsibilities expected from it, to maintain health status by the resources generated, and to perform its responsibility to improve health status. If the health system fails to finance its expenditures through different revenues or is able to fulfill these responsibilities via the Treasury or financial support, the continuity of this assistance will constitute the basis for financial sustainability of the health system (Kalkınma Bakanlı̆̆g, 2014).

One definition says financial sustainability in the health system refers to the ability of a health system to function effectively over time with minimum financial input (Belek, 2009). According to another definition, financial sustainability is the ability of resources to maintain a sufficient level for the functioning of the system (USAID, 2001). Financial stability in the health system, which is described as the alignment of limitless needs and limited financial resources (Eurostat, 2005) is a country's ability to finance its health system by its financial resources in the medium and long term. Financial stability, which has a critical importance in ensuring the continuity of the provision of services and health care in the long run, is the ability to meet health expenditures by revenues obtained via the primary financing mechanism selected 
(Y1ldırım, 2012b). As to Queensland Treasury Corporation (2016), financial sustainability is "being able to maintain infrastructure and manage services through likely policy changes and unexpected financial shocks without the need for economically significant or socially destabilising revenue or expenditure adjustments."

Financial sustainability has also been equated with financially self-sufficiency of the societies to cover the whole health system and the requirements of the program. According to this viewpoint, priorities must be set within government budget constraints, additional resources must be mobilized, and better value must be obtained for funds used in the health sector. A health system's sustainability depends on its operation by an organization with the ability to mobilize and allocate adequate and appropriate resources in the long term (Brenzel and Young, 2011).

\section{CONCLUSION}

The primary objective of any health system is to improve health level of the society. In order to achieve this objective, health services should be accessible, equitable, of quality, and sustainable (Akdağ and Mollahalioğlu, 2011). The fundamental dimension of sustainability in the health system is financial sustainability, which stands at the center of debates about health policy (Thomson et al., 2009). Financial sustainability is critical because of the direct contribution of health to societal well-being (Tsai, 2010). In addition to, sustainability is momentous for the appropriate functioning of health care systems. (Borgonovi et al., 2018).

Factors such as increased accessibility to health services, the impact of the health sector's labor-and technology-intensive nature on cost increases, increased burden of chronic diseases and need for long-term care with ageing population, threats posed by lifestyle and environmental factors, and higher expectations for service supply and quality not only increase cost pressures and health expenditures, but also push countries towards 'sustainable' new searches in their health systems (Özsarı 2013). Sustainability express the capability of health organizations to effectively use available resources to optimize health services' provision and improve achievable health outcomes. (Borgonovi et al., 2018). The create of a sustainable health system depends on the access to durable and non-durable goods related to health, access to capital and adequate resource allocation for such inputs (Uğurluoğlu and Özgen, 2008).

Sustainable health financing requires policies to involve all stakeholders to make the health system viable (Owusu-Seyere and Bagah, 2014). Therefore, governments are expected to offer solutions based on the problems that may arise in sustainability and financial 
sustainability of the health system by focusing on these concepts very carefully and involving stakeholders (politicians, bureaucrats, academicians, health service providers, etc.).

Finally, the financial sustainability of the health system depends on political decisions on how and how much to invest in health and how resources should be collected. The financial sustainability problem is a political issue. Because financial sustainability is linked to revenues, this issue is a problem that creates pressure on public spending for many countries (Özer and Y1ldırım, 2016).

In this study, the concepts of sustainability and financial sustainability in the health system, which are considered as important concepts in health systems, have tried to be explanied and have been comprehensively discussed. The fact that these concepts have not been studied in detail before in the literature in terms of health system, also constitutes the main emergence point of this study. 


\section{REFERENCES}

Abuor, G.O. (2012), Health Care Financing Strategies and Their Impact on Financial Sustainability (Case of Faith Based Hospitals in Kenya), A Research Project Report Submitted in Partial Fulfillment of the Requirements for the Degree of Master of Business Administration of Kenyatta University.

Akdağ, R. ve Mollahalioğlu, S. (2011), Kamu Hastanelerinin Genel Verimliliğinin Değerlendirilmesi Araştırma Raporu. Refik Saydam Hıfsızıssha Merkezi Başkanlığı, Ankara.

Alper, Y. (2011), “Sosyal Güvenlik Reformu ve Finansmanla İlgili Beklentiler”, Sosyal Güvenlik Dergisi, 1(1), $7-47$.

BASYS, CEPS, IRDES and IGSS. (2005), Development of a Methodology for Collection and Analysis of Data on Efficiency and Effectiveness in Health Care Provision. Final Report, Eurostat Grant: N²0023510004 ESTAT/R-3/PT/ar/B2002 E-3. Retrieved from: http://www.basys.de/aktuelles/sha-efficiency.pdf, (Date of access: 12 May 2018).

Belek, İ. (2009), Sağlığın Politik Ekonomisi, Sosyal Devletin Çöküşü. İstanbul: Yazılama Yayınları.

Birch, S. (2014), OHE Lunchtime Seminar: Improving Sustainability through Needs-Based Planning. Retrieved from: https://www.ohe.org/node/1563. (Date of access: 12 May 2018).

Brenzel, L. and Young, D. (2011), Assessment of the Financial Sustainability of the Affordable Medicines FacilityMalaria (AMFm) in Eight Pilot Countries. Information and Discussion Paper, Submitted to the AMFm Unit of the Global Fund to Fight AIDS, Tuberculosis and Malaria. Retrieved from: www.theglobalfund.org. (Date of access: 15August 2018).

Borgonovi, E., Adinolfi, P., Palumbo, R. and Piscopo, G. (2018). "Framing the Shades of Sustainability in Health Care: Pitfalls and Perspectives from Western EU Countries". Sustainability, 10, 4439, doi:10.3390/su10124439.

Campbell, S. Pieters, K., Mullen, K.A., Reece, R. and Reid, R.D. (2011), "Examining Sustainability in a Hospital Setting: Case of Smoking Cessation”, Implementation Science, 6, 108.

Coiera, E. and Hovenga, E.J.S. (2007), Building a Sustainable Health System. IMIA Yearbook of Medical Informatics.

Deloitte, (2012), Sürdürülebilir Kamu İlaç Finansman Modeli İçin Yol Haritası ve Süreç Yönetimi. Retrieved from: http://www.ieis.org.tr/pdfler/Deloitte_kamufinansmanraporu_0612.pdf. (Date of access: 6 August 2018).

Di Matteo, L. (2010), “The Sustainability of Public Health Expenditures: Evidence from the Canadian Federation”, The European Journal of Health Economics, 11, 569-584.

Essink, D. R. (2012), Sustainable Health Systems. The role of Change Agents in Health System Innovation. Faculty of Earth and Life Sciences. Hertogenbosch: Uitgeverij BoxPress.

European Commission, (2013), Investing in Health, Commission Staff Working Document Social Investment Package, Brussels. $\quad$ Retrieved from: http://ec.europa.eu/health/strategy/ docs/swd_investing_in_health.pde. (Date of access: 10August 2018).

European Commission, (2014), Communication from the Commission on Effective, Accessible and Resilient Health Systems. Brussels, 4.4.2014, COM(2014) 215 final.

Eurostat, (2005), Development of a Methodology for Collection and Analysis of Data on Efficiency and Effectiveness in Health Care Provision, Final Report. Retrieved from: http://www.basys.de/aktuelles/shaefficiency.pdf. (Date of access: 7 June 2018).

Figueras, J., McKee, M., Lessof, S., Duran, A. and Menabde, N. (2012), Health Systems, Health, Wealth, and Societal Well-Being: An Introduction. In Figueras, J. \& McKess, M. (Eds). Health Systems, Health, Wealth and Societal Well-Being, Assessing the Case for Investing in Health Systems, World Health Organization. England: McGraw-Hill Open University Press, pp. 1-13.

Göktan, A. (2008), “Türkiye’de Mali Sürdürülebilirlik Üzerine Amprik Bir Çalışma”, Marmara Üniversitesi İİBF Dergisi, 15(2), 425-445.

Gruen, R.L., Elliott, J.H., Nolan, M.L., Lawton, P.D., Parkhill, A., McLaren, C.L. and Lawis, J.N. (2008), "Sustainability Science: An Integrated Approach for Health Programme Planning", The Lancet, 371, 1579-1589. 
Kalkınma Bakanlığı, (2014), Sosyal Güvenlik Sisteminin Sürdürülebilirliği, Özel İhtisas Komisyonu Raporu 2023, Ankara. $\quad$ Retrieved from: http://www.kalkinma.gov.tr/Lists $\quad / z e l \%$ 20htisas\%20Komisyonu\%20Raporlar/Attachments/220/sosyal\%20g\%C3\%BCvenlik\%20sis.OIK.pdf (Date of access: 20 August 2018).

Kaya, A. (2013), Mali Sürdürülebilirlik: Teori ve Türkiye Uygulaması. İstanbul: Türkiye Bankalar Birliği.

Klaus, B. (2010), Developing an Assessment of Organizational Sustainability. Retrieved from: http://www.thesustainablengo.org. (Date of access: 08 August 2018).

Knowles, J.C., Leighton, C. and Stinson, W. (1997), Measuring Results of Health Sector Reform for System Performance: A Handbook Indicators, Special Initiatives Report No.1, Bethesda, MD: Partnerships for Health Reform.

Kuhlman, T. and Farrington, J. (2010), “What is Sustainability?”, Sustainability, 2, 3436-3448.

La Fond, A. (1995), Sustaining Primary Health Care. The Save the Children Fund, London.

Marchildon, G.P. (2004), The Many Worlds of Fiscal Sustainability. In Marchildon, G.P., McIntosh, T. and Forest, P.G. (Eds.). The Fiscal Sustainability of Health Care in Canada. Canada: University of Toronto Press, pp.3

Mathaisel, D.F.X. and College, B. (2014), “A Strategy For Promoting Health Care Sustainability”, The Clute Institute International Academic Conference, San Antonio, Texas, USA.

Miller, T. (2013), "Sustainable Healthcare and the Role of Medical Technology", Arab Health Magazine, 3, 6466.

Murray, C.J. and Frenk, J. (2000), “A Framework for Assessing the Performance of Health Systems”, Bulletin of the World Health Organization, 78(6), 717-731.

Owusu-Seyere, E. and Bagah, D. (2014), "Towards a Sustainable Health Care Financing in Ghana: Is the National Health Insurance the solution?”, Public Health Research, 4(5), 185-194.

Özer, Ö. and Yıldırım, H.H. (2016), “Türkiye Sağlık Sisteminin Finansal Sürdürülebilirliğine Yönelik Bir Uygulama”, Mehmet Akif Ersoy Üniversitesi Sosyal Bilimler Enstitüsü Dergisi, 8(16), 149-161.

Özsarı, H.S. (2013), “Üniversite Hastaneleri, Sürdürülebilirlik ve Güçler Ayrılığı”, Sağlık Düşüncesi ve Tıp Kültürü Dergisi, 20, 40-43.

Prada, G., Grimes, K. and Sklokin, L. (2014), Defining Health and Health Care Sustainability. Ottawa: The Conference Board of Canada.

Queensland Treasury Corporation, (2016), Financial Sustainability in Public Health: The Imperative for Forecasting. AHHA-Innovation Collaboration Network.

Romanow, R.J. (2002), Building on Values: The Future of Health Care in Canada. Final Report. Commission on the Future of Health Care in Canada.

Thomson, S., Foubister, T., Figueras, J., Kutzin, J., Permanand, G. and Bryndová, L. (2009), Addressing Financial Sustainability in Health Systems, WHO, Copenhagen, pp.1-3.

Tıraş, H.H. (2012), "Sürdürülebilir Kalkınma ve Çevre: Teorik Bir İnceleme”, Kahramanmaraş Sütçü İmam Üniversitesi İktisadi ve İdari Bilimler Fakültesi Dergisi, 2, 57-73.

Tordrup, D., Angelis, A. and Kanavos, P. (2013), "Preference on Policy Options for Ensuring the Financial Sustainability of Health Care Services in the Future: Results of a Stakeholder Survey", Applied Health Economics and Health Policy, 11, 639-652.

Tsai, S. (2010), "Understanding the Financial Sustainability of Taiwan's Health System: Modelling Health Expanditure Through 2035”, from: http://tr.scribd.com/doc/108963696/7/SUSTAINABILITY-IN-HEALTHCARE (Date of access: 04 December 2018).

Uğurluoğlu, E. and Özgen, H. (2008), “Sağlık Hizmetleri Finansmanı ve Hakkaniyet”, Hacettepe Sağlık İdaresi Dergisi, 11(2), 133-160.

USAID, (2001), Fundamentals of NGO Financial Sustainability. Retrieved from: (http://www.pathfind.org/site/DocServer/Fundamentals_of_NGO_Financial Sustainability.pdf. (Date of access: 20 September 2018). 
Wang, G.X. (2010), "Financial Sustainability of Universal Healthcare and Its Reform: The Case of Taiwan", Asian Social Science, 6(4), 3-18.

WHO, (2000), The World Health Report 2000: Health Systems-Improving Performance, Geneva pp.5-8.

World Economic Forum, (2012), The Financial Sustainability of Health Systems A Case for Change, A Report from the World Economic Forum. Prepared in collaboration with McKinsey \& Company.

Yıldırım, H.H. (2012a), Sağlık Harcamaları ve Sağlık Finansmanı. In Yıldırım, H.H. (Ed.). Sağlık Sigortacılığı. Eskişehir: Anadolu Üniversitesi Yayını.

Yıldırım, T. (2012b), Türkiye'de Sağlık Sigortacılığının Değerlendirilmesi. In Yıldırım, H.H. (Ed). Sağlık Sigortacılığı, Eskişehir: Anadolu Üniversitesi Yayını.

Yıldırım, T. (2015), Avrupa Birliği, Sağlık Çalışanları ve Türkiye: Serbest Dolaşım ve Potansiyel Göç. Ankara: ABSAM Yayınları. 